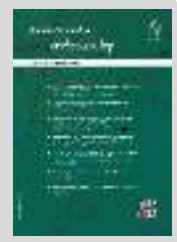

Book Review

\title{
Book Review: Human Osteology in Archaeology
}

\author{
Javad Hoseinzadeh Sadati
}

Assistant Professor, University of Kashan, Kashan, IRAN

\begin{abstract}
"Human Osteology in Archaeology: instructions for how to practice and preserve of human remains in archaeology", written by Milad Hashemi and Hamed Vahdati Nasab (from Department of Archaeology, University of Tarbiat Modares) has been published in 2019 by Nedaye Tarikh publication, and includes 185 pages of contents, pictures, photos, sketches, forms and tables. Publication of this short instructional book is a sign of a need in Iranian archaeological and anthropological spaces for more cares about human remains from archaeological contexts, and the authors aptly response to this necessity. While there are some shortages in book layout and arranging of its contents but from editorial point of view it will satisfy the tastes of its readers. The book has not been divided to different chapters, and its content are aligned according to stages that one wish to starts to study human skeletal remains from its very begging, includes importance of human remains in archaeology, preparation for excavation of human remains, how to document and study them in filed and laboratory, and preserve them during and after studies. Except few cases, the authors properly and precisely covered most fundamental issues that were needed, and with the help of pictures, photos, sketches, forms and tables they tried to convey the abstracts of what is needed to transfer to their readers with respect of the aims of the book.
\end{abstract}

Keywords: Human Osteology, Archaeology, Human Remains, Protection and Preservation

\footnotetext{
* Corresponding author: javadhoseinzadeh@gmail.co

Copyright (2020, the Authors / This open-access article is published under the terms of the Creative Commons Attribution-NonCommercial 4.0 International License which permits Share (copy and redistribute the material in anymedium or format) and Adapt (remix, transform, and build upon the material) under the Attribution NonCommercial terms
} 


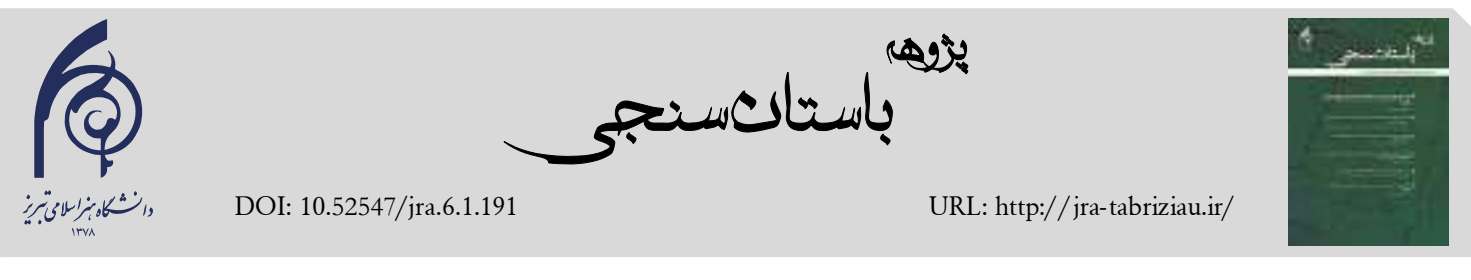

\section{نقد و بررسى كتاب (استخوانشناسى انسانى در باستانشناسى" جواد حسينز اده ساداتى"}

عضو هيئتعلمى گروه باستانشناسى دانشكاه كاشان، كاشان، ايران

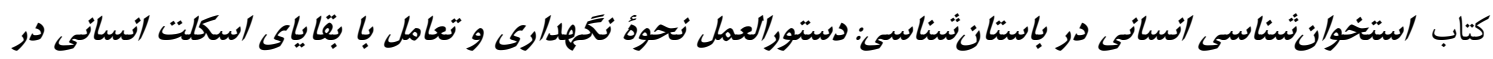

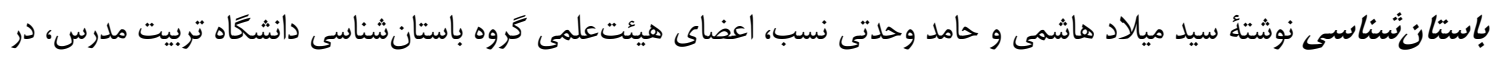

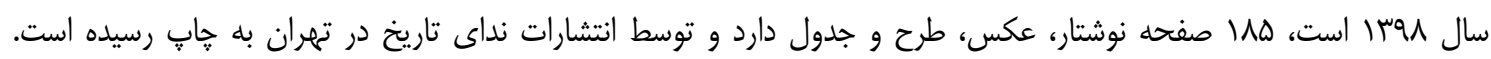

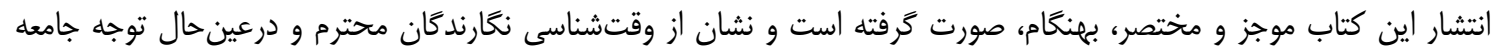

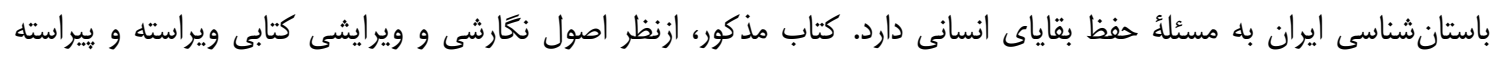

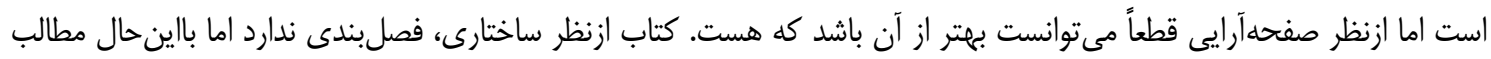

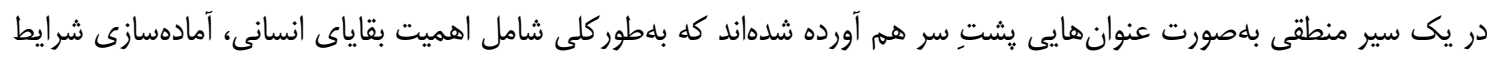

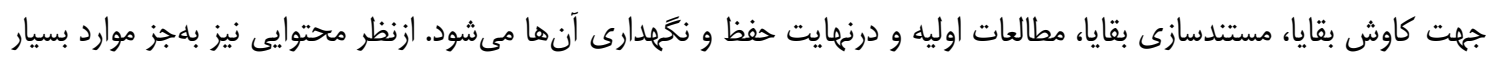

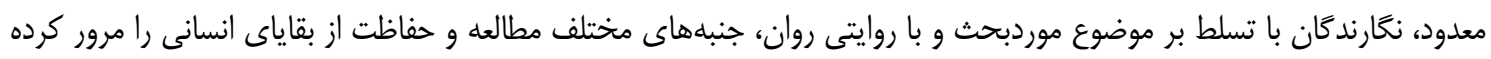

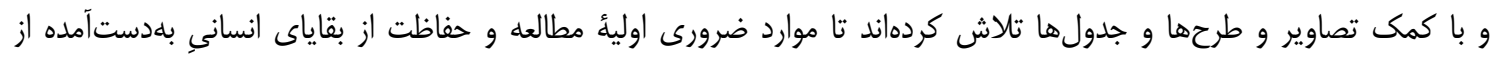

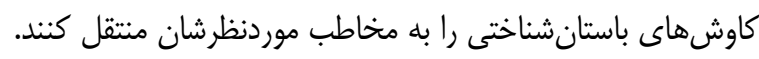

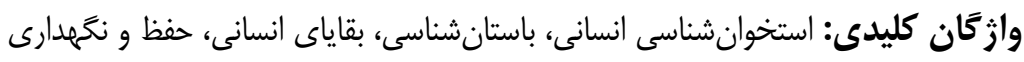

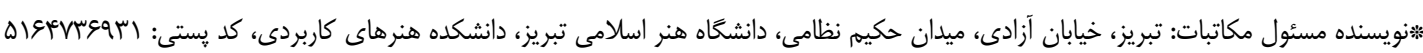
hoseinzadeh@ kashanu.ac.ir آدرس الكترونيكئن

C) حق نشر متعلق به نويسنده(كان) است و نويسنده تحت مجوز Creative Commons Attribution License به مجله اجازه مىدهد مقاله حاب شده را با ديخران به اشتراك بكذارد منوط بر اينكه حقوق مؤلف اثر حفظ و به انتشار اوليه مقاله در اين مجله اشاره شود. 
ما را از كذشتنٔ ايران و بهويـزه دوران يـيشازتـاريخ آن،

دمَركون خواهد كرد.

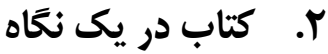

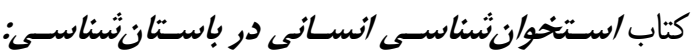

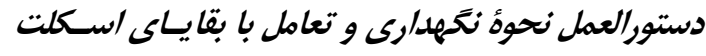

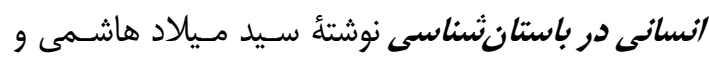

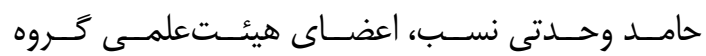
باستانشناسى دانشـعاه تربيـت مـدرس، در سـال يوسا

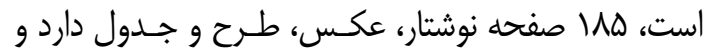

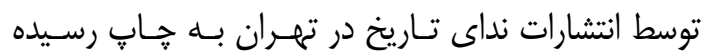
است. طرح جلد كتاب كه توسـط خـانم معصـومه همـراه، طراحىشده شامل تصويرى از جمجمـهـ و وبخـشهـايى از

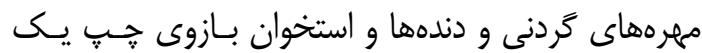

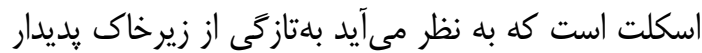

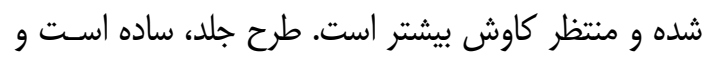
تاندازهاى با محتواى كتاب همخوانى دارد، اما ازآنجايى كه

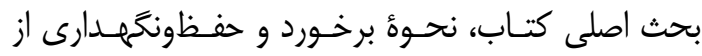

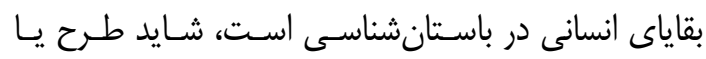

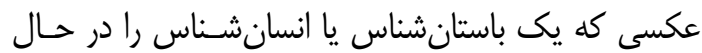
كار روى بقاياى انسانى در يك كـاوش يـا در آزمايشـاه إناه

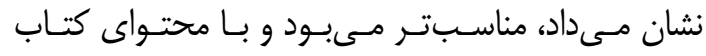
همخوانى بيشترى مى يافت و صــالبته كـه ايـن موضـوع

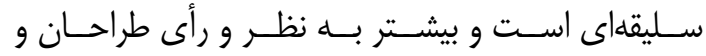
نغارندكان بستخى دارد. باوجوداينكه كتاب ازنظر ساختارى، فصلبندى نــارد

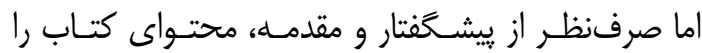

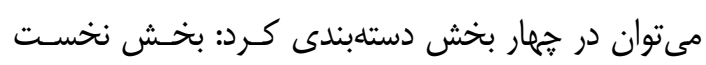

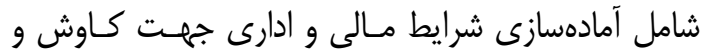

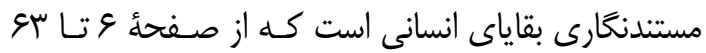

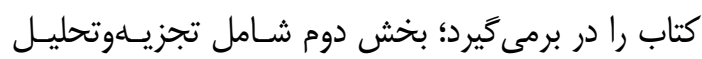

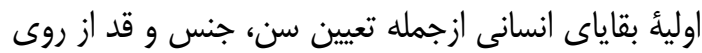

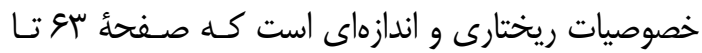

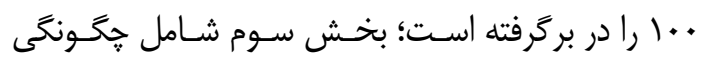
نكَهدارى و بايخانى بقاياى انسانى در آزمايشخاهها و انبارها

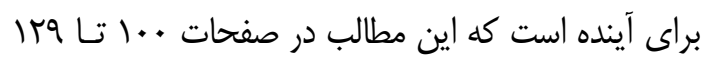

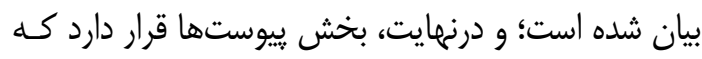

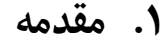

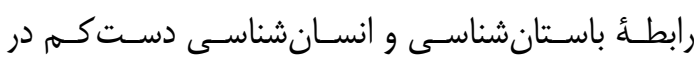

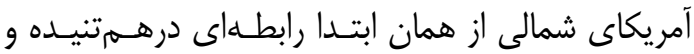

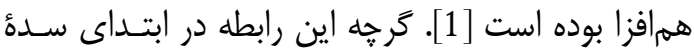

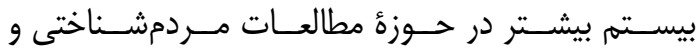
جمجمهسنجى بود، رفتهرفته استفاده از آناليز عنصـرى و ودئر

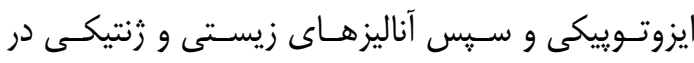

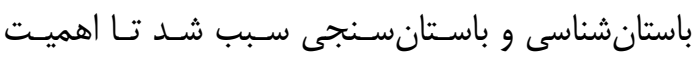
بقاياى انسانى در باسـتانشناسـى دوخنــدان شـود [ب] و و

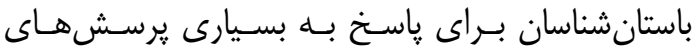

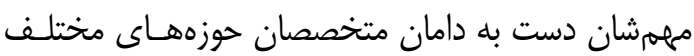
انسانشناسى زيستى شوند كه هم دقيقتر از روشهـاى دهاى

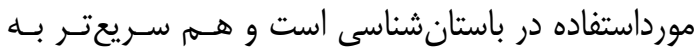

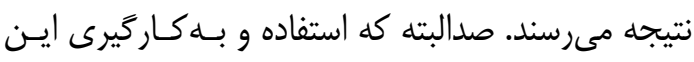

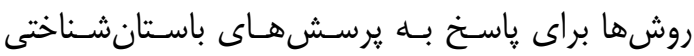

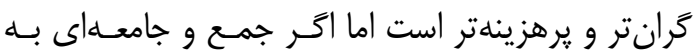
دنبال شناخت درست و دقيق تـاريخ و سركذشت ونت ملـت

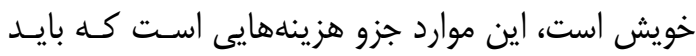

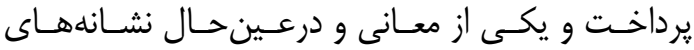

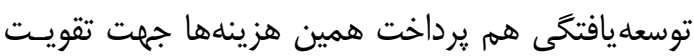

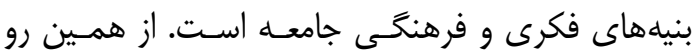
جاى تعجب نيست كه در جامعلة ما كه بلعنوان جامعهاى

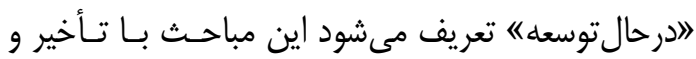
تأخرى طولانى نسبت به جوامع توسعهيافتـه موردتوجـهـ

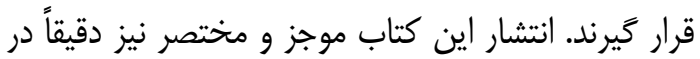

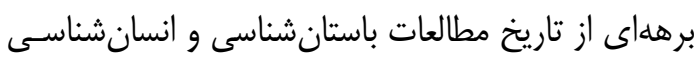

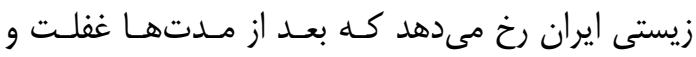

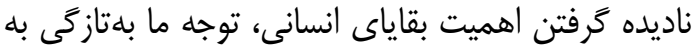

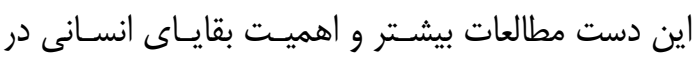
ياسخ به يرسشهاى باستانشناختى در جشم ما روشنتر

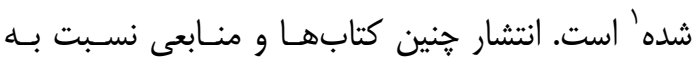

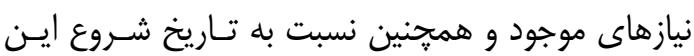
دست مطالعات در ساير كشورهاى دنيا، ديرهنگام به نظر

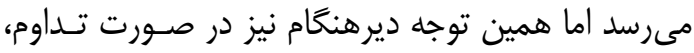
مفيد واقع خواهد شد. قطعاً اين توجه و حساسيت نسـبت ندام ندان

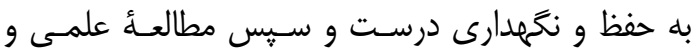
دقيق بقاياى انسانى طى يك دهأ آينده، درك و دريافت 
كه تلاش حرفهاى خاصسى بـراى ييراستتخى صـفحات و

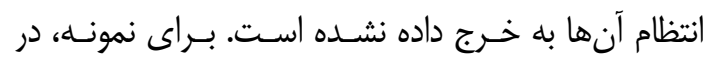

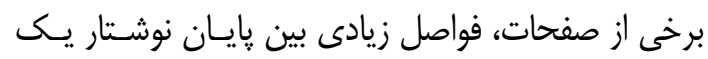

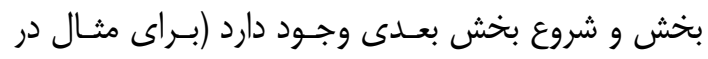

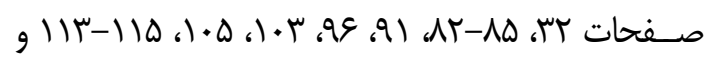

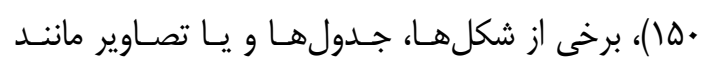

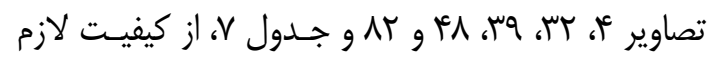

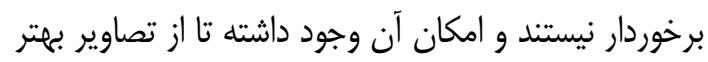

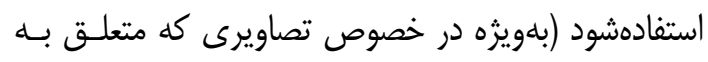

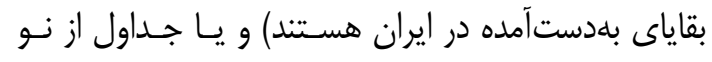

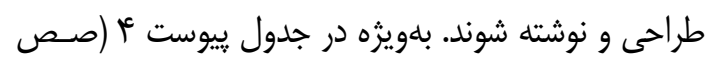

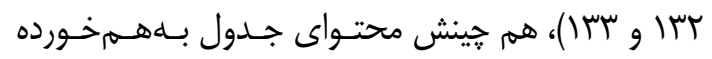

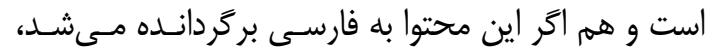

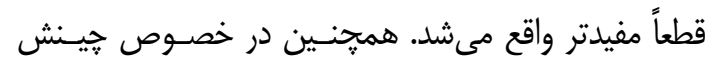

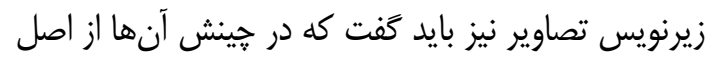

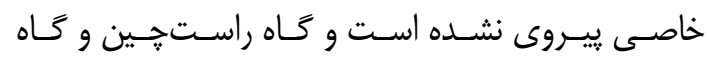

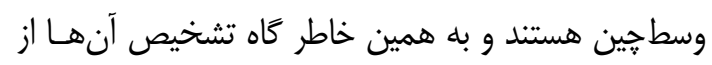

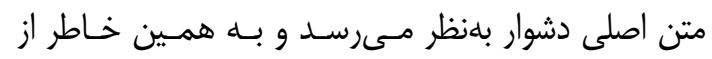

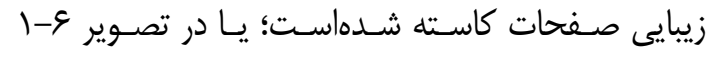

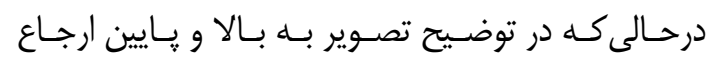

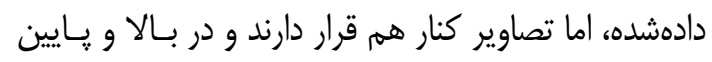

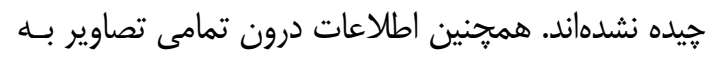

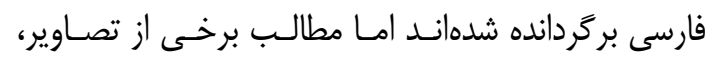

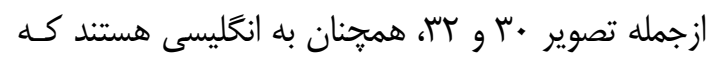

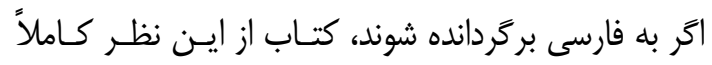

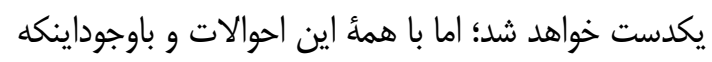
تمامى تصاوير كتاب سياهوسفيد هستند (كه قطعاً به خاطر

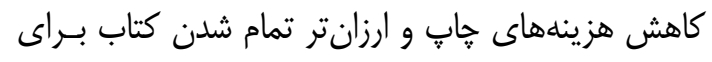

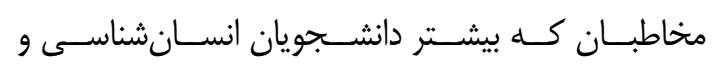

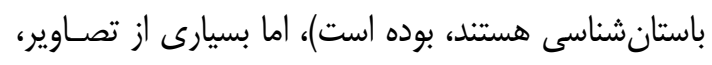

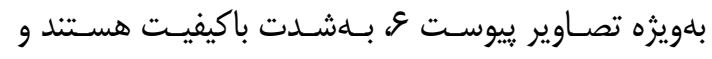

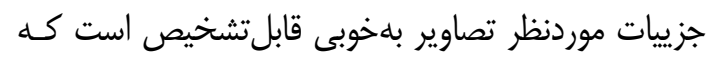

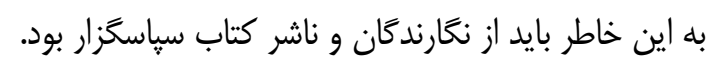

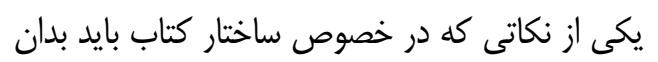

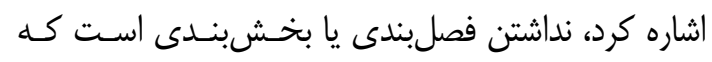

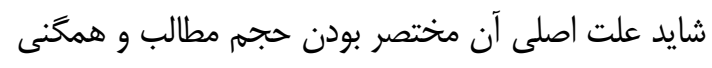

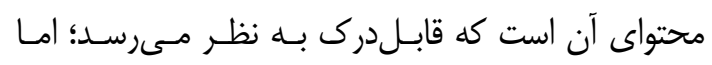
$19 \mu$ سال ششم، شماره دوم، پياييز و زمستان و وسا
شامل شش يبيوست است (ازجملـه تصـاوير و طـرحهـاى

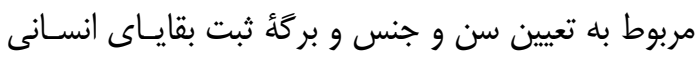

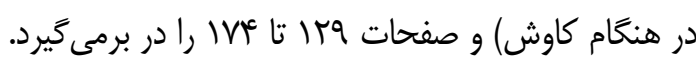

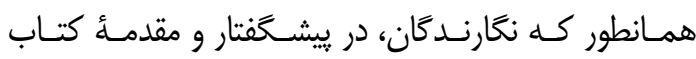

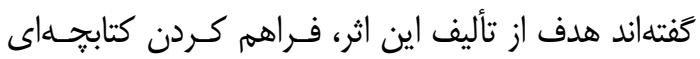

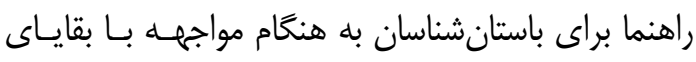

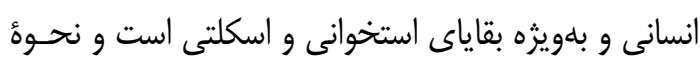

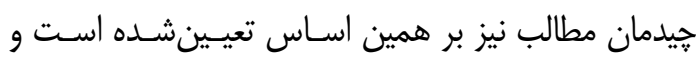

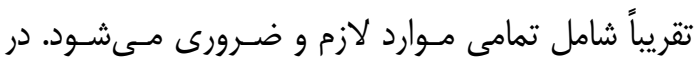

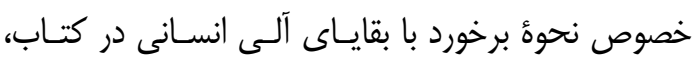

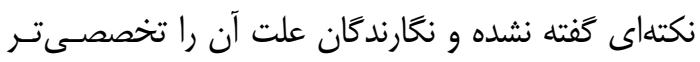

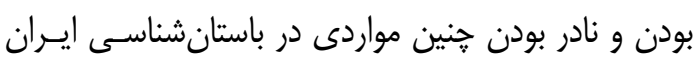

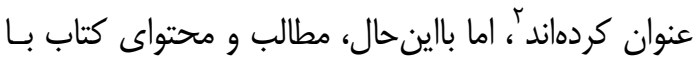

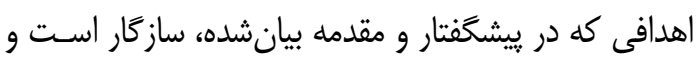
از اين نظر نغارندكان بلهخوبى از عهدة كار بر برآمدهاندا.

\section{". ويخَى هاى نتارشى، وير ايش و ساختارى كتاب}

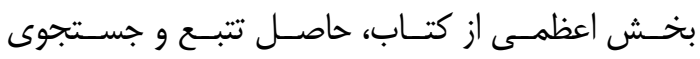

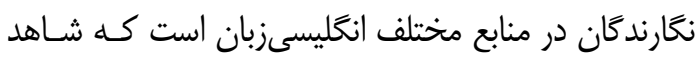

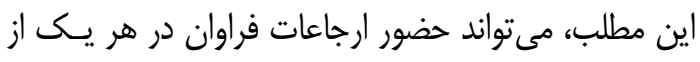

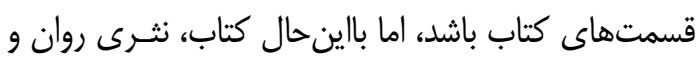

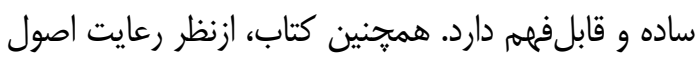

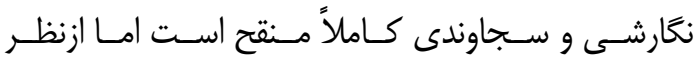

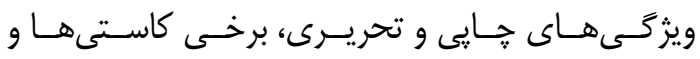

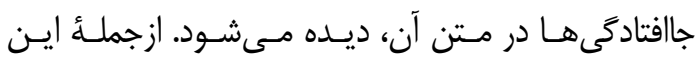

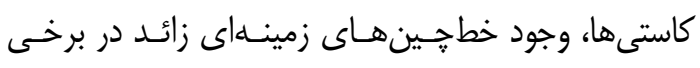

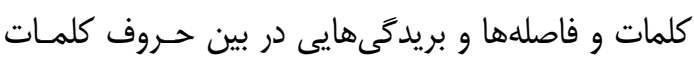
مختلف است كه در صفحات متعددى ديده مى شــود و بــــ

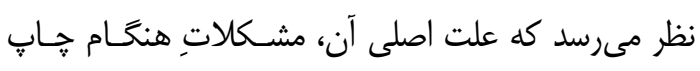

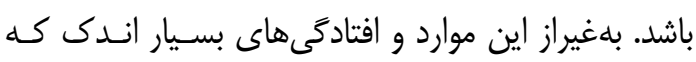

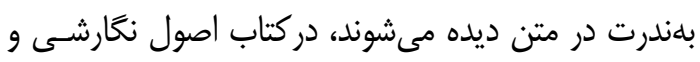

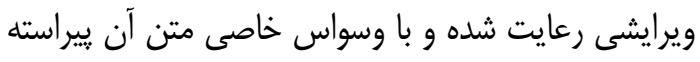
شده است.

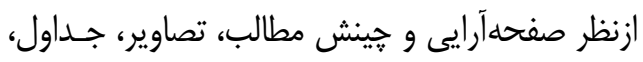
طرحها و بخشبندى بايد كفت كـه كتـاب، آن جنـان كـهـ

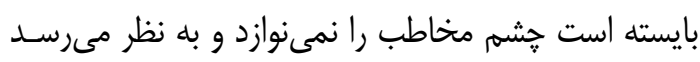


ارجاع دادهشه است كه تقريباً همخى ارتباط مستقيمى بـا

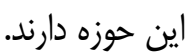

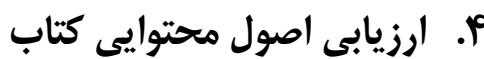

كتاب ازنظر محتوايى با اهتمام تـام و تمـام، آنجـهـ را كـهـ

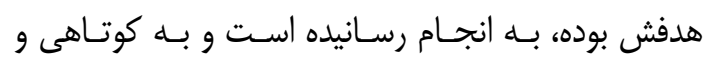

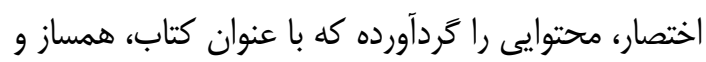

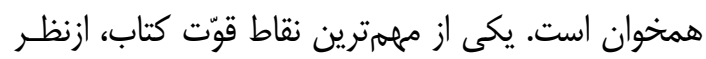

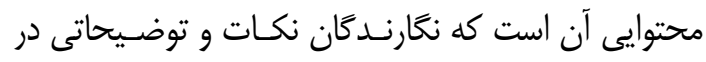

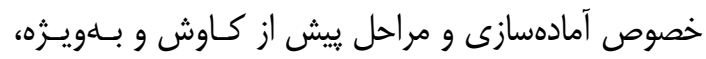

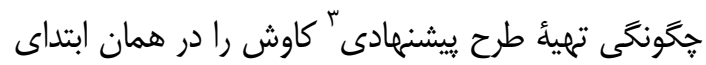

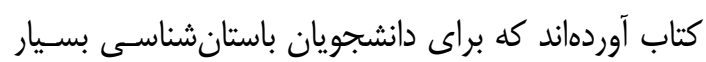

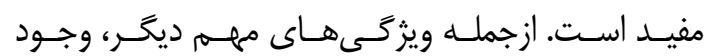

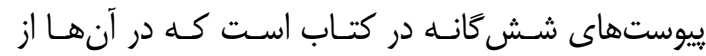

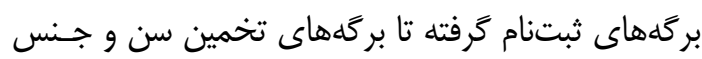

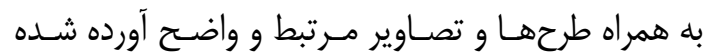
است كه آنهم به تقويت محتواى كتاب مى افزايد.

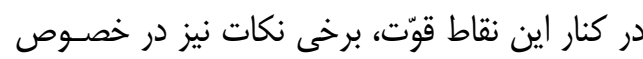

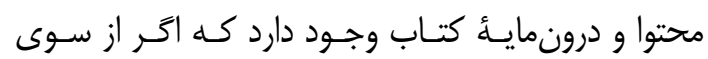

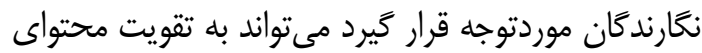

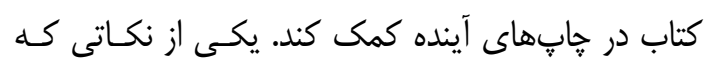

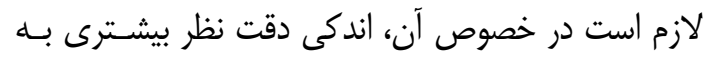

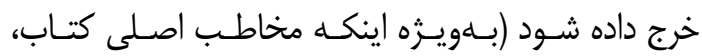

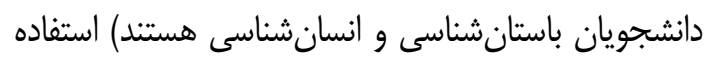
از برخى وازمهاى انغليسى يا غيرفارسى است كه معـادلى

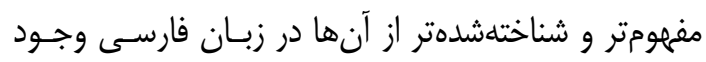

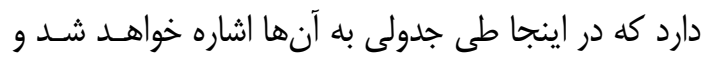
اميد است نغارندكان محترم در ويراست آتى كتاب، آنهـا

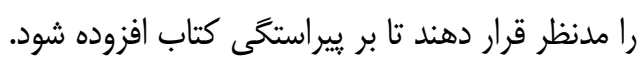

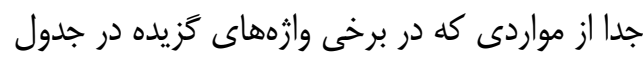

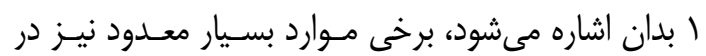

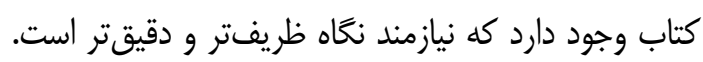

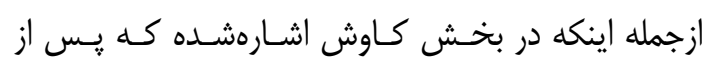

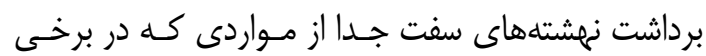
وازمهاى كزيده در جدول البدان اشاره شده، برخسى مـوارد

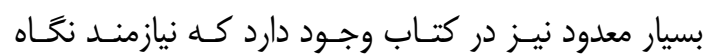

نكتهاى كه شايد از جشم نغارندكان ينهان مانده باشد، آن

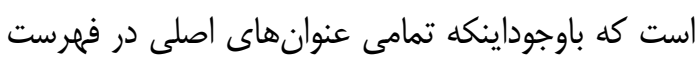

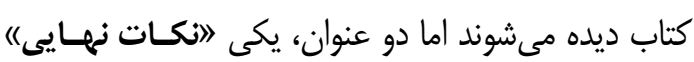

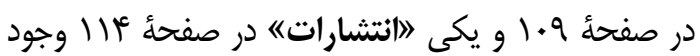

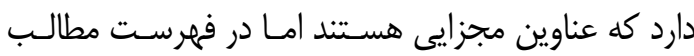

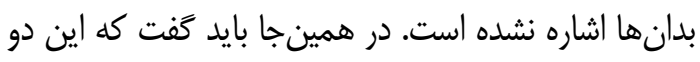

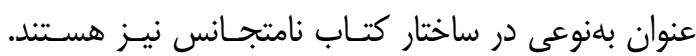

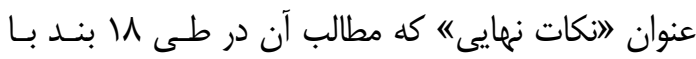

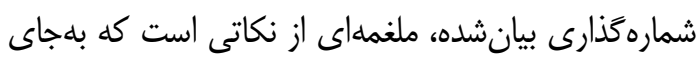

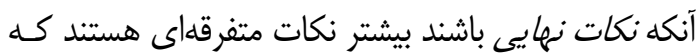

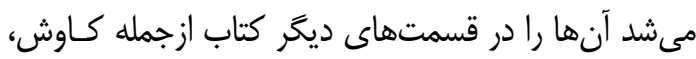

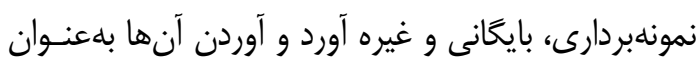

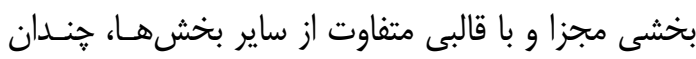

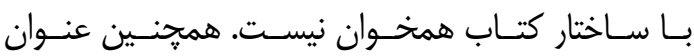

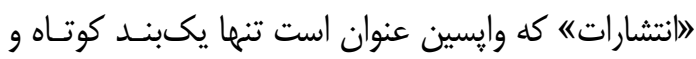

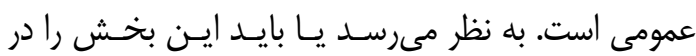

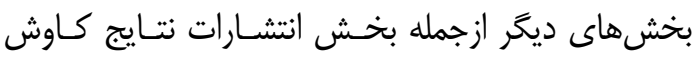

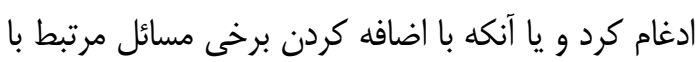

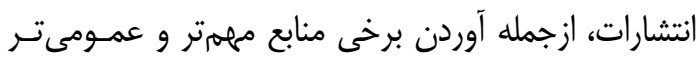

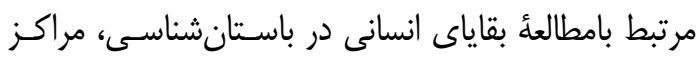

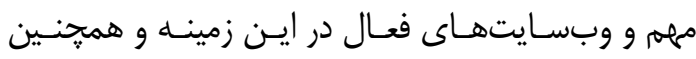

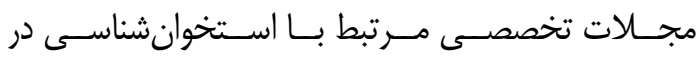
باستانشناسى اين بخش، را فربهتر كرد و بهعنوان بخشى

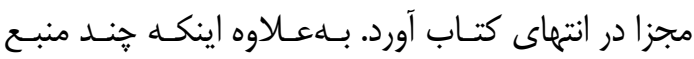

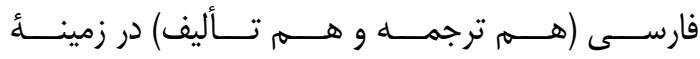

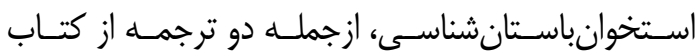

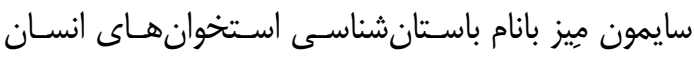
(يكى توسط مازيار اشرفيان بناب [2] و يكى توسط سميه

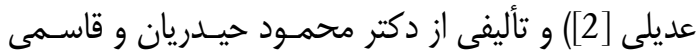

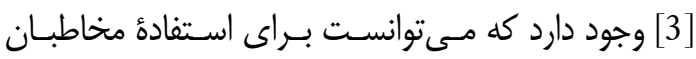

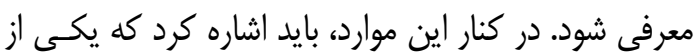

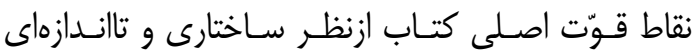

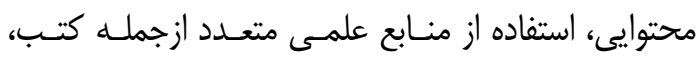
مقالات، بيانيهها، دستورالعمل ها، كزارشها و و دركَاهــاى

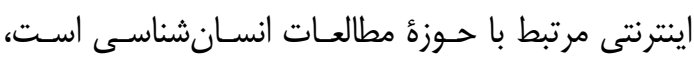

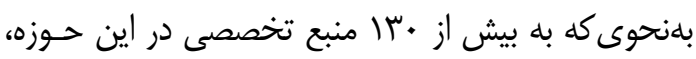

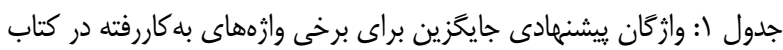


Table 1: Suggested alternative words to some of the words used in the book

\begin{tabular}{|c|c|c|}
\hline وازه ييشنهادى & وازه مورداستفاده در كتاب & وازه انغَليسى \\
\hline كروه & ديارتمان & Department \\
\hline قشرى & كورتيكال & Cortical \\
\hline درونأست & غشاى اندرونى & Endosteum \\
\hline حفره مغز استخوان & كانال مدولارى & Medullary Cavity \\
\hline كارگاه-گمانه & ترانشه & Trench \\
\hline عارضه & فيجر & Feature \\
\hline نواريبجى & بانداز & Bandage \\
\hline قالب بندى-برداشت قالبى & بلو كهبردارى & Blocking \\
\hline بافت باستانشناختى & بافت باستان شناسى & Archaeological Context \\
\hline ستروَن & استريل & Sterile \\
\hline بخت & شانس & Chance \\
\hline زيست باستانشناسى & باستانشناسى زيستى & Bio-Archaeology \\
\hline فرايندهاى يس از انباشت & تفانومى & Taphonomy \\
\hline بخش انتهايى & بخش انتهايى دور & Distal End \\
\hline بخش ابتدايى & بخش انتهايى نزديك & Proximal End \\
\hline ساييدگى سطح مفصلى/ساييدگى مفصلى & تباهى سطوح مفصل & $\begin{array}{c}\text { Articular Joint Disease/Degenerative } \\
\text { Joint Disease }\end{array}$ \\
\hline بركه & فرم & Form \\
\hline
\end{tabular}

فراهم كـردن بسـترى نـرم آنهــا را درون يـا روى ينبـهـ

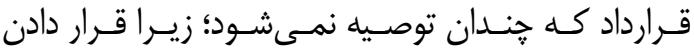
اسـتخوان در درون هـر نـوع كيسـهُ يلاسـتيكي دربسـته

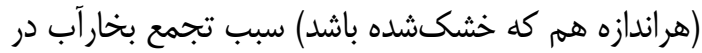

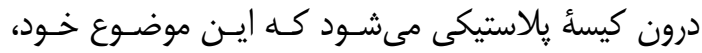

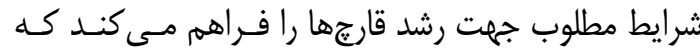

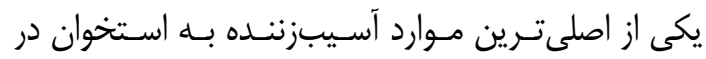

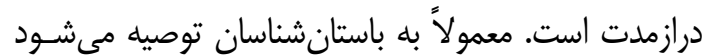

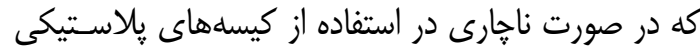

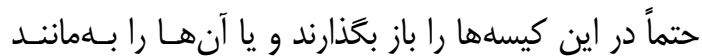

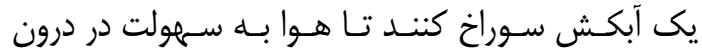
كيسهها جريان داشـته باشـــ و سـبب تجمـع بخــارآب در

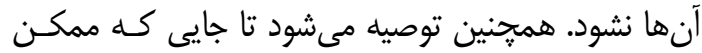
است استخوان بلهورمستقيم با ينبه در ارتباط نباشد و بين ينبه و استخوان لايهاى از كاغذ، يارجه يا مواد بدون يرز و و

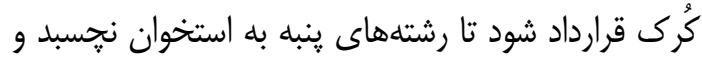

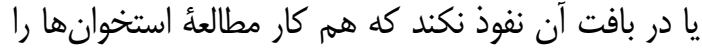
سخت مى كند و هم در آينده ممكـن اسـت سـبب ايجـاد
ظريفتر و دقيقتر است. ازجمله اينكه در بخـش كـاوش

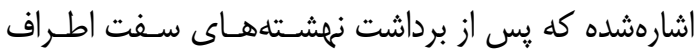
استخوان، بهتر است كه از برس (فرجه يا قلهمـو)، يـوار و

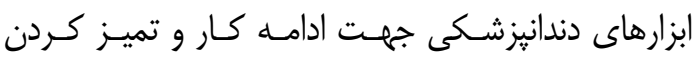
استخوان استفاده شود. اين توصيه كاملاً درست است امـا

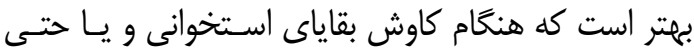

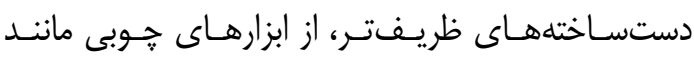
كاردكهاى مجسمهسازى و حتى خلال هاى جوبى كبابى كه نوك تيز و درعين حال مقاوم هستند، استفاده شود؛ زيرا

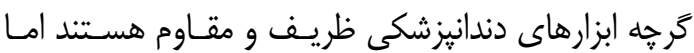

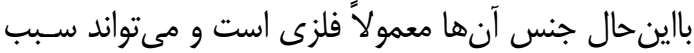

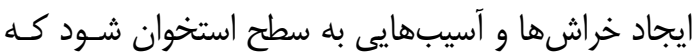

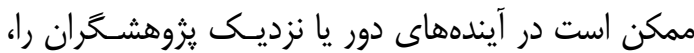
بلهويزه به هنگًام انجام آزمايشها و بررسى هاى تصـويرى و بصرى، گمراه كند.

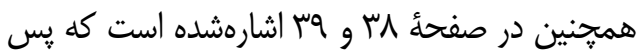
از انجام كارهاى ثبتنام ميدانى و جهت انتقـال اسـتخوان

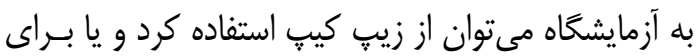


كار يكى از بخشهاى سخت آموزش بـهـ افـراد تـازهكـار

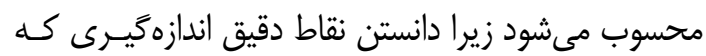

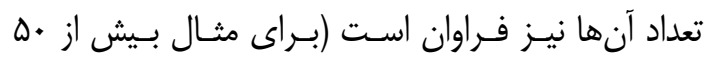

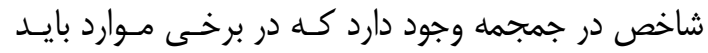

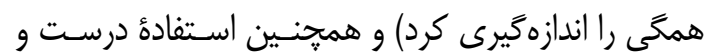

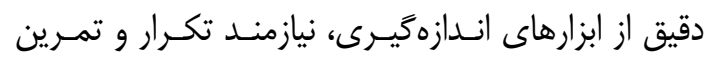

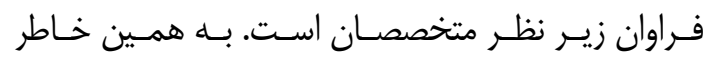

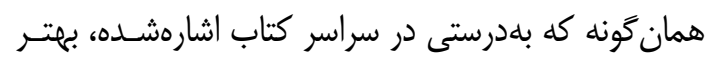

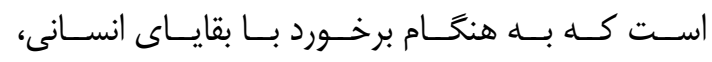

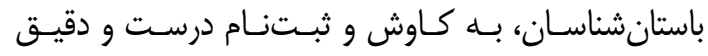

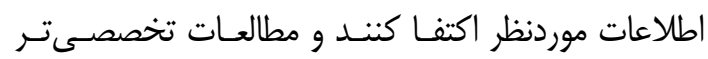

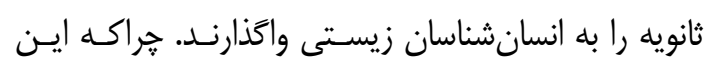

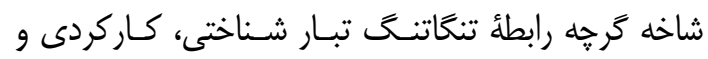

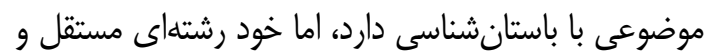

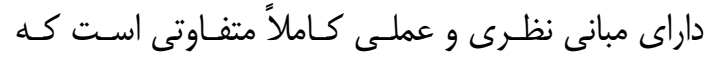
فعاليت در آن نيازمند آموزش تخصصى و و رسمى بلندمدت

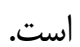

\section{ه. نتيجل كيرى}

كتاب/ستخوانشناسى در باستانشناسى نوشتئ دكتر ميلاد

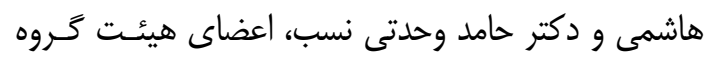

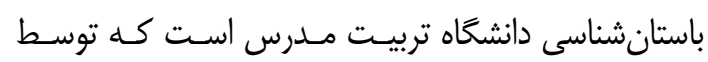

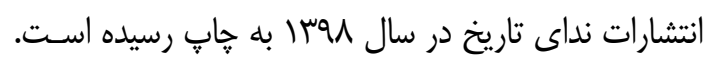

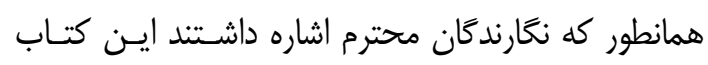
حاصل احساس يك نياز در فضاى باستانشناسـى ايـران،

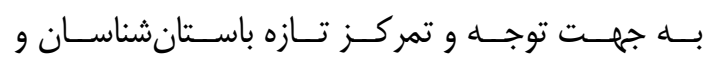

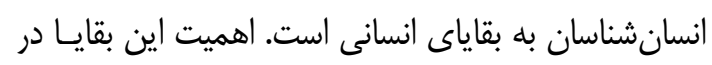

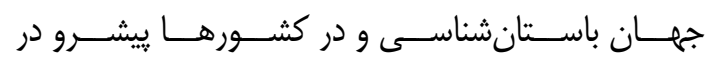

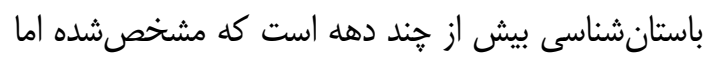

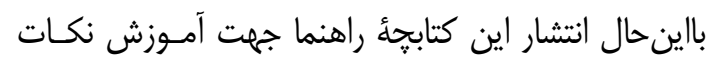

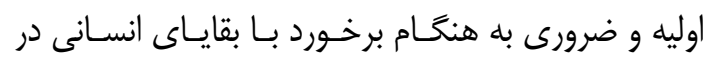

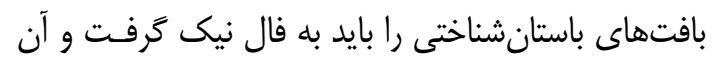

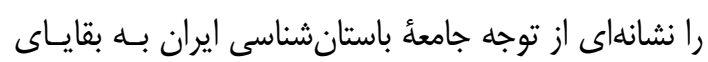

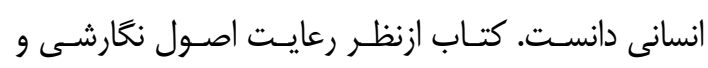

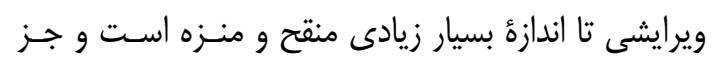

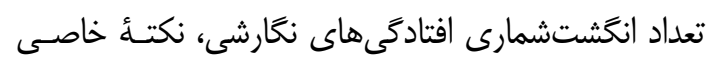

خطا در كارهاى آزمايشكاهى شود.

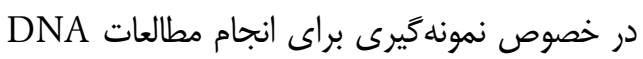

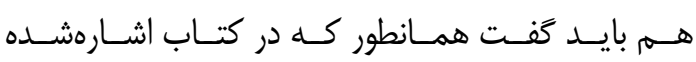

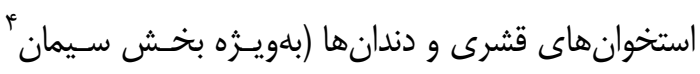

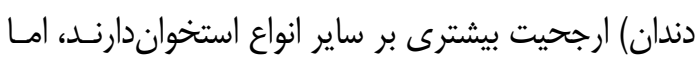

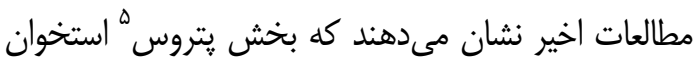

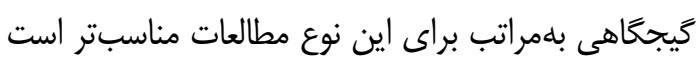

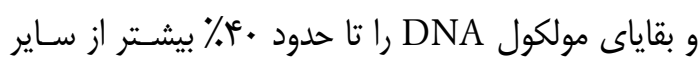
بخشهاى اسكلتى در خود نكَه مى دارد [F].

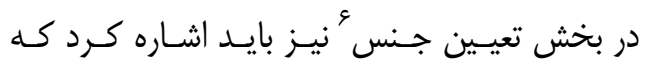

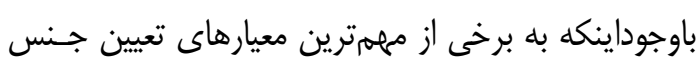

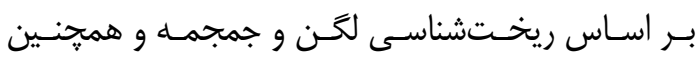

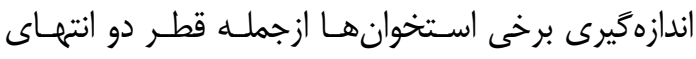

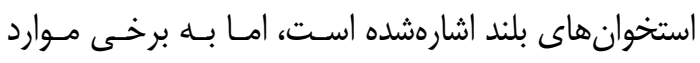

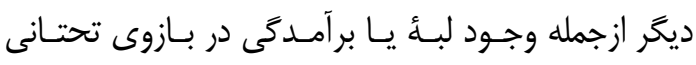
استخوان شرمكاه (Pubic) در لكن [2] و و تفاوت در انــازه و شكل سطح مفصلى استخوان تهيخاه و استخوان خـاجى أنى

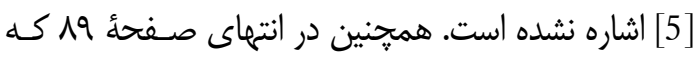
به وجود قوس شكمى در استخوان محل اتصال استخوان

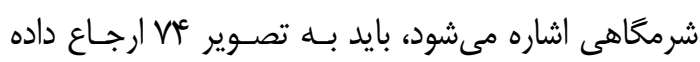

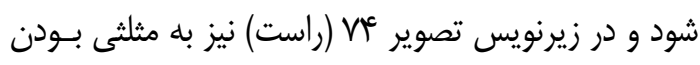

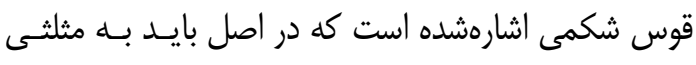

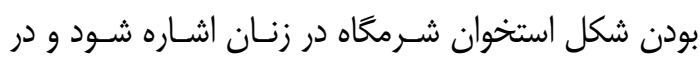

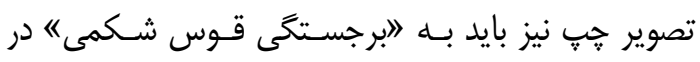

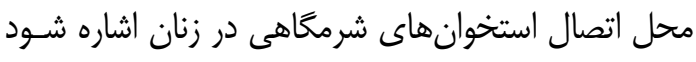

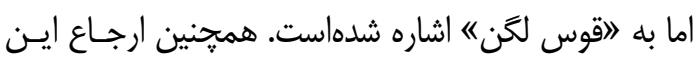

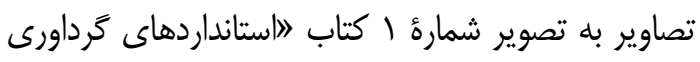
دادها از روى بقاياى انسانى" نوشتهٔ بويكسترا و اوبلاكِكر

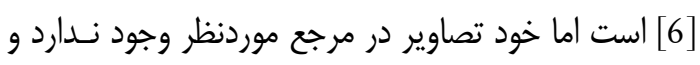
شايد علت عدم همخوانى تصاوير و توضيحات تصاوير نيز

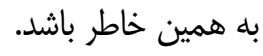

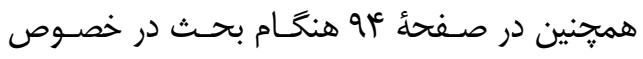

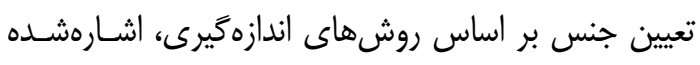

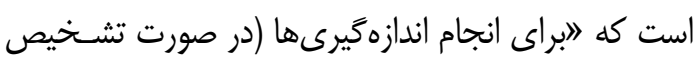

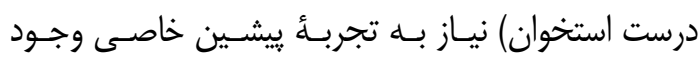

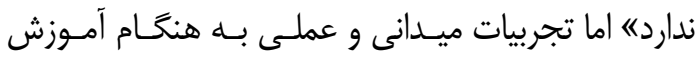
اندازمكيرىها به دانشجويان نشان مىدهد كه درواقع ايـن 


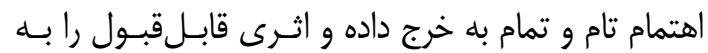
مخاطبان عرضه كردهاند.

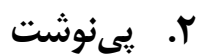

1. از جمله فعاليتهايى كه اين توجه را نشان مىدهد مسىتوان

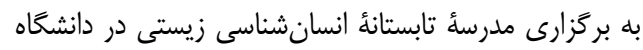

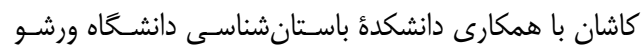

http://www.antropologia.uw.edu.pl/en/s ummer-school-iran/overview.html )، ايجــاد (umb مراكز زيست باستانشناسى در دانشعاه كاشان و تمهـران

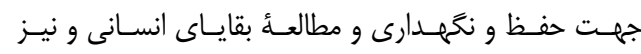

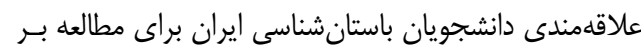

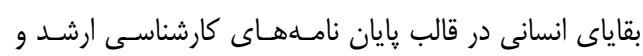

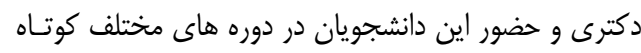
مدت و بلندمدت انسانشناسى در ايـران و بيـرون از ايـران

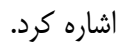
r.

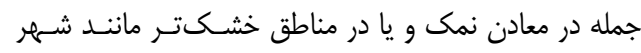

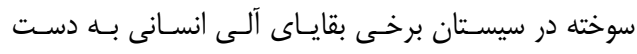

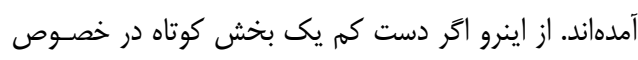

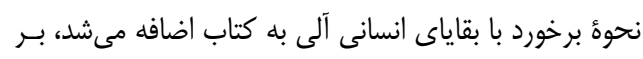

3. Proposal

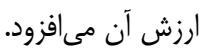

4. Cement

5. Petrous: با بخش خارواى

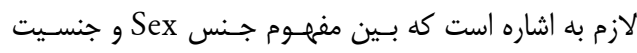

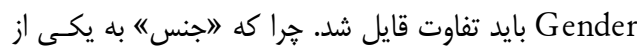

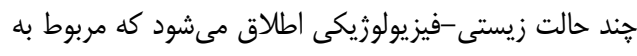

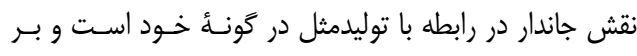

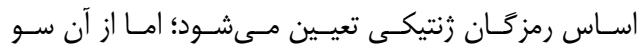

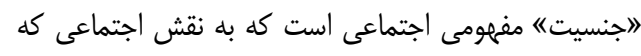

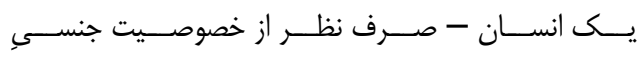

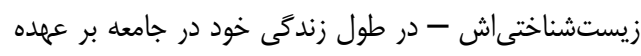

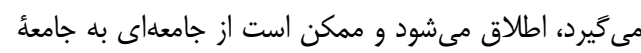

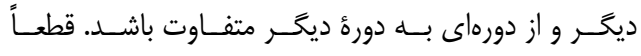

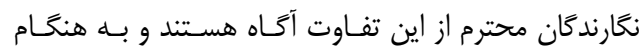
ويراستارى، اين مطلب از حشم آنها ينهان آنهان مانده است.

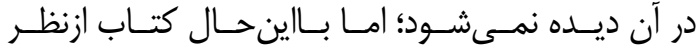

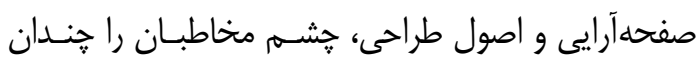

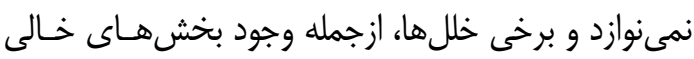

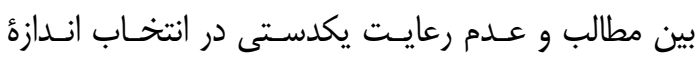

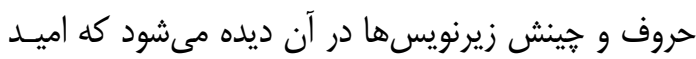

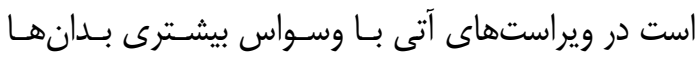

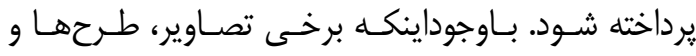

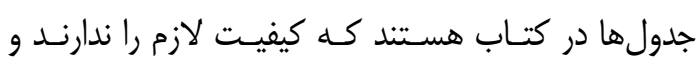

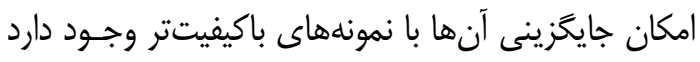

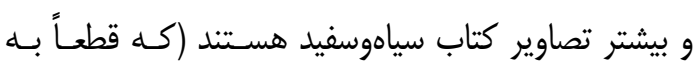

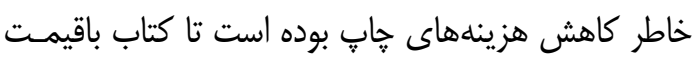

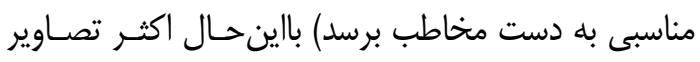

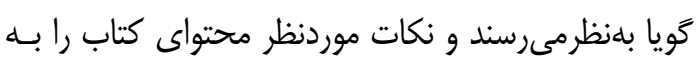
مخاطب مىرسانند. ازنظر ساختارى و محتوايى نيز كتاب تا اندازهٔ زيـادى به هدف و آرمان خود نزديك شده است. كتاب بــه زبـانى

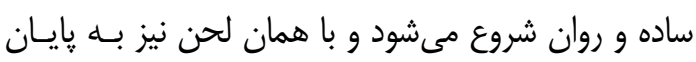

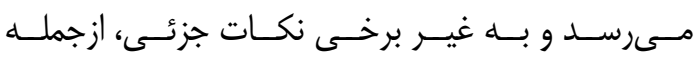

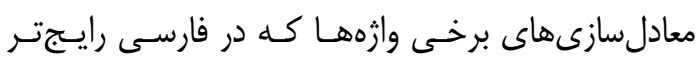

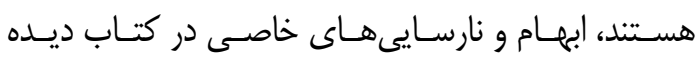

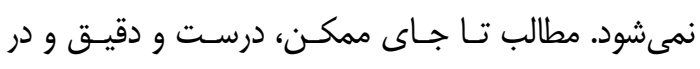

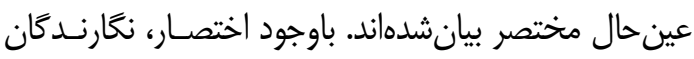

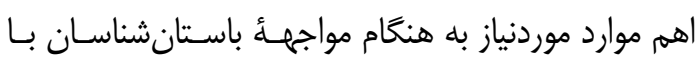
بقاياى انسانى و نحوه برخورد با آن را بيان كردهاند و كمتر

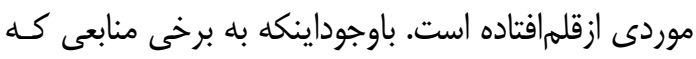

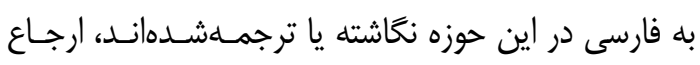

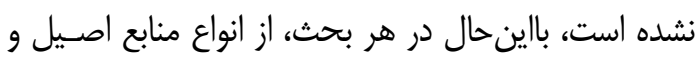

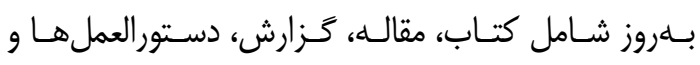

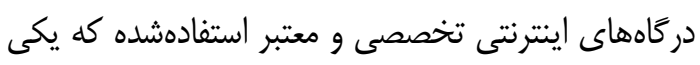

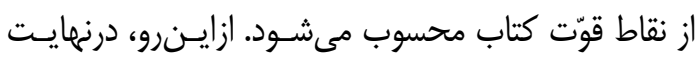
بايد قدردان تلاشهاى نغارندكان محترم كتاب بود كه درد

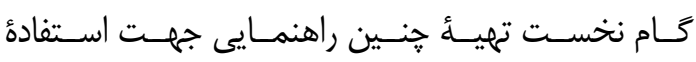

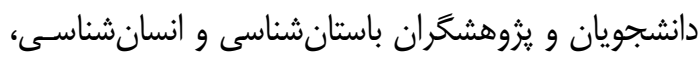




\section{References}

[1] Willey G, Philip P. Method and Theory in American Archaeology, University of Chicago Press, Chicago. 1958.

[2] Mayes $S$.the Archaeology of Human Bones, Routledge. 2001.

[مِيز سيمون. باستانشناسى استختوانهـاى انسـان،

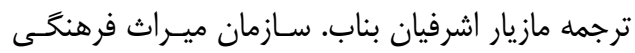

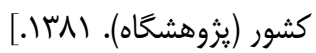

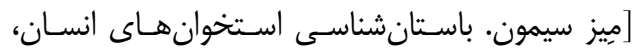

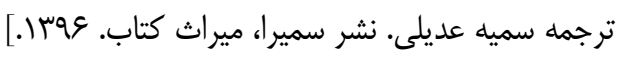

[3] Heidarian M, Ghasemi, B. Osteology in Archaeology. Jahad Deneshgahi. 2016. [In Persian]

] حيدريان محمود، قاسمى بهنـام. استختوانشناسـ در

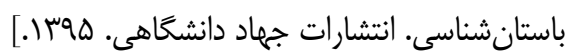

[4] Hansen HB, Damgaard PB, Margaryan A, Stenderup J, Lynnerup N, Willerslev E, Allentoft ME. Comparing ancient DNA preservation in petrous bone and tooth cementum. PLOS ONE. 2017: 12 (1): e0170940.

doi:10.1371/journal.pone.0170940.

[5] Valojerdy MR, and Hogg DA. Sex differences in the morphology of the auricular surfaces of the human sacroiliac joint. Clinical Anatomy. 1989: (2): 63-67. doi.org/10.1002/ca.980020203.

[6] Buikstra JE, Ubelaker D. Standards for data collection from human skeletal remains. Proceeding of a Seminar at the Field Museum of Natural History. Arkansas: Arkansas archeological survey research series no 44. 1994. 